\title{
Varieties of Responsible Management Learning: A Review, Typology and Research Agenda
}

\author{
John G. Cullen ${ }^{1} \mathbb{B}$
}

Received: 26 March 2018 / Accepted: 13 November 2019 / Published online: 25 November 2019

(c) Springer Nature B.V. 2019

\begin{abstract}
Over the past two decades an increasing number of research papers have signalled growing interest in more responsible, sustainable and ethical modes of management education. This systematic literature review of peer-reviewed publications on, and allied to, the concept of responsible management learning and education (RMLE) confirms that scholarly interest in the topic has accelerated over the last decade. Rather than assuming that RMLE is one thing, however, this review proposes that the literature on responsible management education and learning can be divided into four distinct categories: (1) Teaching Responsible Management; (2) Organizing for Responsible Education; (3) Responsible Individual Learning, and; (4) Responsible Organizational Learning. Although the literature on RMLE has grown, work on how managers learn responsible management in organizational or workplace settings, particularly without the intervention of external educational providers, is minimal. The Special Issue of the Journal of Business Ethics is the first to address this significant lacuna. The vast majority of published peer-reviewed research is related to organizational provider-centric organizing for responsible management education. Each category is explored and the implications of organizing the literature this way for the field of RMLE are discussed. Finally, an agenda for future research and theory development on RMLE is proposed.
\end{abstract}

Keywords Ethical issues in management education $\cdot$ Responsible management education $\cdot$ Responsible management learning

\section{Introduction}

One of the more recent introductions to the lexicon of business and society has been 'responsible management education', a term whose popularity has been bolstered by the initiation of the Principles of Responsible Management Education (PRME) component of the United Nations Global Compact. The addition of 'responsible' to management education and learning has encouraged management educators to find ways to promote progressive environmental, social and cultural values amongst students and faculty colleagues. Does this introduction of the concept of 'responsibility'

Electronic supplementary material The online version of this article (https://doi.org/10.1007/s10551-019-04362-x) contains supplementary material, which is available to authorized users.

John G. Cullen

john.g.cullen@mu.ie

1 School of Business, Maynooth University, Maynooth, Co. Kildare, Ireland mean something different for professionals and managers who, in the words of the call for paper for this Special Issue of the Journal of Business ethics, 'in their organisational environments learn for sustainability, responsibility and ethics' (Laasch 2017, p. 2). This paper demonstrates that the vast majority of research on responsibility in management education to date has been conducted with formal institutionalized education in mind, and significantly less attention has been afforded to how individuals 'do' responsible management learning in practice.

Aguinis and Glavas' (2012) review of the literature on Corporate Social Responsibility attempted to highlight 'what we know and do not know' (p. 932) about CSR. This paper attempts to provide a similar overview of the field of responsible management learning and education. It does this through a systematic review of published peer-reviewed research on the concepts of responsible management education and learning (hereafter RMLE) with the aim of identifying different forms of responsible management learning and education. Articles on responsible management education and related topics found in two general academic research 
databases (the Social Sciences Citation Index and Academic Search Complete), one business research database (Business Source Complete), one leading education database (ERIC) and one specialist listing dedicated to collecting literature relevant to the field of responsible management (the Centre for Responsible Management Education's Responsible Management (RM) Literature Base).

Although some researchers have expressed concern about the lack of unified, agreed definitions concepts such as sustainability, business ethics, or responsible management (Marshall and Toffel 2005; Schwartz and Carroll 2008; Nonet et al. 2016), it is important to recognize that the absence of shared terminology can also signal the evolution of nascent fields of inquiry and practice. Thus, rather than attempting to provide a meta-definition for responsible management learning, this article aims to map the topography of the area with the aim of assisting researchers to ascertain where they may locate and develop their work. In doing so, it clearly demonstrates that there is only a small body of existing research literature in the space of this Special Issue of the Journal of Business Ethics.

The manner in which this article does this is outlined below. Firstly, an outline of the method used, including the rationale for selecting particular data sources, is provided. The search strings utilized are described and the data reduction and analysis strategy is outlined. 'Headline' results are reported before the rationale for organizing the literature into four sections (Teaching Responsible Management; Organizing for Responsible Learning; Responsible Individual Learning, and; Responsible Organizational Learning) is presented. The main themes which characterize the literature in each section is outlined. Each section ends with a summary of the future research needs which have been articulated in the literature for each category.

Next, a research agenda is for RMLE is presented and the implications of these findings for management education and learning is discussed. Finally, the limitations of the study are considered, key findings and proposals are outlined and avenues for future research in all four types of RMLE are discussed. The main contributions of this paper are summarized in the 'Summary and conclusions' at the very end of the paper.

\section{Method}

The research for this paper began by identifying published peer-reviewed research on the concept of RMLE and related topics found in two general academic research databases (the Social Sciences Citation Index and Academic Search Complete), one business research database (Business Source Complete), one leading education database (ERIC) and one specialist dataset on the field of responsible management (the Centre for Responsible Management Education's Responsible Management (RMLE) Literature Base). These databases were searched using the term 'Responsible Management Education' as a string within the title, subject keywords and abstract fields (in the SSCI the latter two fields are amalgamated with the title field in the 'topic' field). In order to ensure that the search was conducted as thoroughly as possible in both Business Source Complete and Academic Source Complete the search strings were searched as 'subject terms' 'abstract' and author supplied 'keywords'. Only peer-reviewed academic journal results were recorded. ERIC results were searched in the fields of 'Abstract', 'Subject Heading' or 'Identifier (Keyword)'. The titles, abstracts and subject keywords of all of the peer-reviewed articles listed on the peer-reviewed research titles listed on the CRME Responsible Management Literature Base. Although some of these titles were working papers which have not yet been published in peer-reviewed journals, and did not meet the criteria for inclusion in this systematic literature review, they made substantial contributions to the theorisation of responsible management learning and were given full consideration in the development of the typology which this article contributes. Initial searches on Business Source Complete, the Social Sciences Citation Index, and Academic Source Complete were undertaken on 16th June 2016. Subsequent searches were undertaken on 29th November 2016 and August 29th 2017. A final search was undertaken on all of these databases and the Centre for Management Education Literature Base on 28th September 2018 and the findings are discussed in this article. In order to ensure that the broadest possible range of findings could be researched strings associated with the responsible management education were searched. These included 'Responsible Management Educat*', 'Responsible Management Learn*', 'Responsible Management Train*', 'Responsible Human Resource Development', 'Responsible Management Teach*' and 'Responsible Management Educat*'. The * wildcard enabled a broader set of results to be returned. For example, the search term 'Responsible Management Learn*'allowed the return of learning, learners, etc. to be returned.

The CRME 'Responsible Management Learning and Education (RMLE)' literature base (2018) listed 76 titles as of the start of October 2018. As this paper solely focuses on articles published in peer-reviewed scholarly periodicals, five working papers (Laasch and Moosmayer 2015a, b; Laasch 2016, 2017), 11 monographs (Mocny and Laasch 2010; Education 2012; Csuri et al. 2013; Murray et al. 2014; Laasch and Conaway 2015; Gudic et al. 2016; Laasch and Conaway 2016; Rimanoczy 2016, 2017; Moosmayer et al. 2019) and one book chapter (Waddock et al. 2010) and one book review (Lenn 2015), which were otherwise highly 
relevant to the field of RMLE, had to be excluded from the analysis. The results of the initial findings are reported in Table 1.

From these initial results, it is clear that most work has been published in the field of 'responsible management education'. When articles related to responsible management (as opposed to RMLE) were excluded from the CRME RMLE database, 21 additional articles were isolated and included in the review. When duplicate records were removed from this search, 60 records were returned. As this paper focuses on peer-reviewed research literature, 6 articles from nonpeer-reviewed sources (magazines and trade journals) were removed from the search. When duplicates, non-English papers, editorial introductions and articles which referred to the search stings in incidental ways were removed from the search, 3 additional articles were added. In total, 102 articles were selected for review.

The journal which published most of the papers identified was the Journal of Management Education (29 papers), all of which appeared in the Special Issue 'Principles for Responsible Management Education' $(15,2)$ which was published in 2017. A quantitative ranking of all journals which included articles selected for analysis is included in Table 2.

The search demonstrated that articles on RMLE began to be published around 2007 (shortly after the establishment of PRME) and this number, although still small has increased in recent years (see Fig. 1). Data collection for this research ceased on October 1st 2018, but 8 relevant articles were identified at this point.

Just under half of the articles analysed were essays that described experiences introducing PRME or opinion pieces on the importance of introducing forms of responsible management education into curricula and teaching practice. These essays consisted of diverse pieces such as resource reviews, descriptions of educational programmes, operational processes, commentaries on other PRME-related articles calls for papers. Three were book reviews. Two articles were interviews with individuals connected with PRME and one was a letter. 46 articles (45\%) reported the results of empirical research.

Countries in every continent were discussed in many of the articles analysed, and some discussed responsible management as an international and/or global concern. Twenty-nine of these articles adopted an entirely qualitative approach and 12 were quantitative in nature. Three used mix research methods and two were expressly critical in their orientation. A huge range of specific methods were used in the articles; including: content analyses, surveys, ethnographic case studies, interviews, literature reviews, reflexive journals, critical discourse analyses, etc.

Of these empirical articles twenty-one focused on business school managers, faculty and administrators while 15 were specifically concerned with students. Four articles were concerned with executives, CEOs, managers or entrepreneurs and 3 investigated these three groups together. PRME was mentioned in 22 of the 46 empirically oriented articles. As all the articles variously discussed different groupings and subjects it was possible develop a framework to describe the various literatures with the RMLE field. The process of developing this literature is described in the section 'Organizing the RMLE research literature' below.

\begin{tabular}{|c|c|c|c|c|}
\hline \multirow[t]{2}{*}{ Database } & \multicolumn{4}{|l|}{ Search string } \\
\hline & $\begin{array}{l}\text { Responsible man- } \\
\text { agement educat* }\end{array}$ & $\begin{array}{l}\text { Responsible man- } \\
\text { agement learn* }\end{array}$ & $\begin{array}{l}\text { Responsible human } \\
\text { resource development }\end{array}$ & $\begin{array}{l}\text { Responsible man- } \\
\text { agement develop- } \\
\text { ment }\end{array}$ \\
\hline \multicolumn{5}{|l|}{ Business } \\
\hline Title & 27 & 0 & 0 & 0 \\
\hline Topic & 78 & 0 & 1 & 0 \\
\hline \multicolumn{5}{|c|}{ Social sciences citation index } \\
\hline Title & 5 & 0 & 0 & 0 \\
\hline Topic & 16 & 0 & 1 & 0 \\
\hline \multicolumn{5}{|c|}{ Academic source complete } \\
\hline Title & 1 & 0 & 1 & 0 \\
\hline Topic & 0 & 0 & 0 & 0 \\
\hline \multicolumn{5}{|l|}{ ERIC } \\
\hline Title & 5 & 0 & 1 & 0 \\
\hline Topic & 9 & 0 & 1 & 0 \\
\hline \multicolumn{5}{|c|}{ CRME RMLE } \\
\hline Title/Topic & 55 & 1 & 0 & 2 \\
\hline
\end{tabular}


Table 2 RMLE articles ranked by journal coverage

\begin{tabular}{|c|c|}
\hline Journal title & Frequency \\
\hline International Journal of Management Education & 19 \\
\hline Journal of Management Education & 11 \\
\hline Journal of Management Development & 11 \\
\hline Journal of Business Ethics & 8 \\
\hline Academy of Management Learning \& Education & 6 \\
\hline Journal of Corporate Citizenship & 5 \\
\hline Vision & 4 \\
\hline Journal of Management Inquiry & 3 \\
\hline SAM Advanced Management Journal & 3 \\
\hline Business \& Professional Ethics Journal & 2 \\
\hline $\begin{array}{l}\text { International Journal of Sustainability in Higher Educa- } \\
\text { tion }\end{array}$ & 2 \\
\hline Journal of Cleaner Production & 2 \\
\hline Management Learning & 2 \\
\hline DLSU Business \& Economics Review & 1 \\
\hline SCMS Journal of Indian Management & 1 \\
\hline African Journal of Business Ethics & 1 \\
\hline Journal of Strategic Management Education & 1 \\
\hline African Journal of Business Ethics & 1 \\
\hline Business \& Society Review & 1 \\
\hline Business Management Dynamics & 1 \\
\hline Central European Business Review & 1 \\
\hline DLSU Business \& Economics Review & 1 \\
\hline Higher Education Research \& Development & 1 \\
\hline Human Resource Development Quarterly & 1 \\
\hline IBA Journal of Management \& Leadership & 1 \\
\hline International Journal of Project Management & 1 \\
\hline International Small Business Journal & 1 \\
\hline Journal of Education for Business & 1 \\
\hline Journal of Global Responsibility & 1 \\
\hline Journal of Higher Education Theory and Practice & 1 \\
\hline Journal of Innovation Economic \& Management & 1 \\
\hline Journal of International Business Education & 1 \\
\hline Journal of Strategic Management Education & 1 \\
\hline Operations Management Education Review & 1 \\
\hline Organization \& Management & 1 \\
\hline Problems and Perspectives in Management & 1 \\
\hline Social Business & 1 \\
\hline $\begin{array}{l}\text { The International Journal of Effective Board Perfor- } \\
\text { mance }\end{array}$ & 1 \\
\hline Zietschrift Fuer Wirstchafts und Unternehmenethik & 1 \\
\hline Total & 102 \\
\hline
\end{tabular}

\section{Organizing the RMLE Research Literature}

Cullen and Turnbull's (2005) meta-review of the research literature on management development proposed that it could be divided into two main categories. The first of these categories consisted of studies which approached management

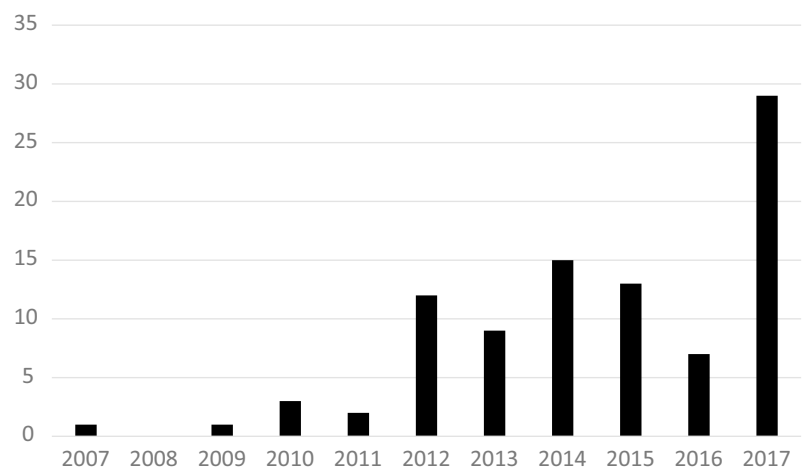

Fig. 1 Number of RMLE articles published by year (2007-2017)

development from the perspective of the provider and the second category was concerned with the perspective of the learners who received or processed learning.

This axis was applied to the literature studied in this review. Papers which emphasize the perspectives of business school faculty and administrators and institutional concerns are referred to as provider-centric studies of RMLE. Papers which emphasize the perspectives of learners (business school students, managers participating in learning initiatives and their sponsoring organizations) are learner-centric RMLE studies. As the analysis of data progressed, it was noticeable that there was also a division amongst papers which focused on the initiatives and activities of individuals (as teachers or learners) and organizations (business schools, universities or sponsoring work organizations). These additional levels of differentiation made it possible to further separate the work studied in this review. When these two axes (provider-centric Vs learner-centric, and, individual Vs organizational) were applied, a dual-axis model for analysing the literature was possible and this model is presented in Table 3.

Articles which report research from a provider-centric perspective and focus on the individual level are categorized as 'Teaching Responsible Management' papers. These articles tend to be written from the perspective of individual teachers and explore areas such as the effectiveness of specific pedagogical initiatives. Provider-centric research which focuses on business school or university initiatives to introduce or improve social or environmental responsibility in their activities are categorized as 'Organizing for Responsible Management'. Most of the articles discuss issues in relation to the implementation of PRME in Business Schools.

Articles which apply a learner-centric perspective to the level of the individual learner have been placed in the category of 'Responsible Individual Learning'. These articles are interested in how students or executives participating in a learning initiative learn about responsible management or work practices. Finally, articles that demonstrate 
Table 3 Categories of RMLE

\begin{tabular}{|c|c|c|}
\hline & Provider-Centric & Learner-Centric \\
\hline Individual Level & $\begin{array}{l}\text { TEACHING RESPONSIBLE } \\
\text { MANAGEMENT } \\
\text { (Primary focus is on teachers } \\
\text { and individual providers of } \\
\text { RMLE. Discusses pedagogical } \\
\text { approaches, assessments and } \\
\text { taught content) }\end{array}$ & $\begin{array}{l}\text { RESPONSIBLE INDIVIDUAL } \\
\text { LEARNING } \\
\text { (Primary focus is on the individual } \\
\text { learner. Explores processes which } \\
\text { influence how students and } \\
\text { managers 'learn' responsibility) }\end{array}$ \\
\hline Organisational Level & $\begin{array}{c}\text { ORGANIZING FOR } \\
\text { RESPONSIBLE } \\
\text { MANAGEMENT } \\
\text { EDUCATION } \\
\text { (Primary focus is on Business } \\
\text { Schools and institutional } \\
\text { providers of RMLE. Discusses } \\
\text { issues related to developing } \\
\text { RMLE as an organisational } \\
\text { capacity amongst providers) }\end{array}$ & $\begin{array}{c}\text { RESPONSIBLE } \\
\text { ORGANIZATIONAL } \\
\text { LEARNING } \\
\text { (Primary focus is on the } \\
\text { organization or workplace as the } \\
\text { learner. Explores processes of } \\
\text { responsible organisational } \\
\text { learning and change at an } \\
\text { organisational or group, rather } \\
\text { than individual, level) }\end{array}$ \\
\hline
\end{tabular}

a learner-centric focus at the organizational (as opposed to individual) level are categorized as 'Responsible Organizational Learning'. Such articles were interested in large scale organizational change or organizational learning initiatives which aim to be ethical in both their practice and outputs.

\section{Teaching Responsible Management (TRM)}

The term 'Responsible Management Education' was used in a number of articles, but it is used here to refer to papers that were primarily concerned with issues such as pedagogical approaches used by individual teachers (Kelley and Nahser 2014; Siqueira and Ramos 2014; Aragon-Correa et al. 2017; Neal 2017; Tyran 2017), the content of taught of modules (Viswanathan 2012; Verbos 2016; Annan-Diab and Molinari 2017; Parris and McInnis-Bowers 2017; Warwick et al. 2017; Cicmil and Gaggiotti 2018), or the form of assessment applied to these modules (Tyran 2017; Stough et al. 2018). Although these articles often discussed students, their primary focus was on the individual provider of responsible management education (i.e. the teacher). A number of authors (e.g. Moratis 2014; Cornuel and Hommel 2015; Sampere 2015; Moratis 2016) abbreviated 'Responsible Management Education' as RME, but for the purposes of this categorization, it is referred to as Teaching Responsible
Management (TRM). This group of articles were the third largest studied in this dataset and amounted to 18 articles. 4 of the eighteen articles found in this category reported the findings of empirical research. Two of these articles utilized a research approach that was primarily quantitative.

Although some articles described the design and delivery of sustainability and social responsibility-oriented modules (Siqueira and Ramos 2014; Parris and McInnis-Bowers 2017) or used established international standards to embed PRME into teaching (Moratis 2013), two related themes dominated articles in the TRM category. The first theme was concerned with directly addressing the challenges faced by individual faculty members who deal with the contradictions involved in delivering forms of management and business education which are socially and environmentally responsible. The second TRM theme is concerned with the need to address the supposed 'value-neutrality' of mainstream business education at the level of the teacher.

The contradictions of teaching responsible management learning centre on the tensions between teaching in a way which advocates for a world which is environmentally and socially sustainable, but also generates profits for private companies (Aragon-Correa et al. 2017; Neal 2017). Although these two principles are not mutually exclusive, Aragon-Correa et al. (2017) and Cicmil and Gaggiotti 
(2018) point out that there is a huge paucity of resources available to teachers who wish to embed forms of responsible management learning into their teaching practice. Beddewela et al's (2017) research on PRME engagement found that 'misalignment between faculty skills and institutional bureaucracy, together with an inconsistent focus on responsible management across the curriculum raises key challenges for its adoption' (p. 263). A significant TRM challenge is not just addressing the inconsistencies and conflicts between teaching social and environmental responsibility and the requirements of capitalism, but also institutional barriers that can unintentionally inhibit responsible management educators (Solitander et al. 2012; Beddewela et al. 2017). Teachers who thus attempt to 'champion' and practice forms of responsible management education (Solitander et al. 2012) must demonstrate a high level of reflexive practice to address and accommodate paradoxes that exist between different disciplines who inform sustainable education (AnnanDiab and Molinari 2017), and indeed the contradictions that remain unresolved within the field of sustainable education development itself (Stough et al. 2018).

The second TRM theme is concerned with engaging with the supposed 'value-neutrality' of traditional management education. This is not a new concern and established management education theorists such as Bennis (2005), Mintzberg (2004) and Ghoshal (2005) have long pointed out the dangers of teaching management as if it were a detached discipline based on economic and 'scientfic' principles rather than a social and organizational practice. The TRM theorists have re-emphasized the need to clarify the values of faculty members in order to clarify the nature of RMLE which is espoused and the approaches which are used to teach responsibility. Some articles highlight the importance of moving management education away from a values-neutral stance towards a more 'humanistic' values-driven stance (Kelley and Nasher 2014; Tripathi et al. 2014). Asirvatham and Humphries-Kil (2017) explore the implications of adopting feminist perspectives by teachers and faculty interested in 'doing' RMLE. As 'received' mainstream models of management education struggle to accommodate these responsible approaches, alternative modes are proposed in the TRM literature which encompass relational complexity and phronesis (Cicmil and Gaggiotti 2018), pragmatic inquiry (Kelley and Nahser 2014), interdisciplinary approaches (Kelley and Nasher 2014; Annan-Diab and Molinari 2017), active and experiential learning (Siqueira and Ramos 2014; Heaton 2017).

Four of the articles identified potential areas of future research as more longitudinal research to assess the ongoing impact of RME, and PRME-based, initiatives beyond the classroom in the actual field of business and the working and personal lives of participants and students. According to the literature explored in the TRM category, the responsibility for delivering RMLE is often passed to faculty who not only have to engage with inherent contradictions within the field, but also with institutional and cultural issues which present faculty with barriers which make Teaching Responsible Management more problematic. A clear research need exists for exploring the experiences and strategies of RMLE-oriented faculty as they engage with these issues. The findings of this research might be of utility beyond the management classroom; Laasch (2018) has demonstrated that conceptualisations of responsible management practice have moved away from being the preserve of specialists or organizational functions, to being part of the everyday work of individual managers in all functions. There are many similarities between the manager and the teacher at 'the coalface' who attempt to integrate responsibility-based principles with their everyday work practices.

\section{Organizing for Responsible Management Education (ORME)}

The articles in this category are also concerned with RMLE, but mainly in terms of developing it as a capacity within Business Schools (Bendell 2007; Rasche and Escudero 2009; Murphy et al. 2012; Prandini et al. 2012; Araç and Madran 2014; Burchell et al. 2015; Nonet et al. 2015). The 'Organizing for Responsible Management Education' category (hereafter ORME) is the largest of all four categories and accounts for 49 , or $48 \%$ of all articles analysed. However, only 20 articles in this category reported empirical research findings, and the others tended to discuss ORME in editorials, reports, essays, interviews etc., rather than research it.

ORME involves overcoming cultural and/or institutional barriers to making Business Schools more responsible and sustainability-oriented. Whereas articles in the TRM category report on responsibility-focused initiatives of individual faculty, articles in the ORME category concentrate on the organizational provider, such as the Business School (Nonet et al. 2015; Snelson-Powell et al. 2016; Greenberg et al. 2017; Kolb et al. 2017) and/or the university (Décamps et al. 2017). Many of these articles recognize the existence of a dominant paradigm of profit-maximization as a key value within Business Schools (Rasche and Escudero 2009; Amann 2011; Millar and Koning 2018) that can only be overcome by interrogating and challenging it.

Many of the articles in this category perceive engagement with PRME as being a central driver of this change, (for example Prandini et al. 2012; Cornuel and Hommel 2015; Dyllick 2015; Verbos and Humphries 2015a, b; Rive et al. 2017; Rosenbloom et al. 2017; Goodpaster et al. 2018; Millar and Koning 2018). PRME is named in 35 of the 49 articles in this category and it is the central topic of focus in many of them. Articles in the ORME category tend to 
focus on the challenges faced by Business Schools in moving to more responsible modes of operating. Those that focus mainly on organizational development at the business school level often propose ways of helping business schools to overcome barriers to change (Young and Nagpal 2013; Cornuel and Hommel 2015; Doherty et al. 2015; Nonet et al. 2015; Painter-Morland 2015; Greenberg et al. 2017) and to support internal faculty 'champions' for PRME education (Nonet et al. 2015; Greenberg et al. 2017).

About half of the articles articulated a variety of future research needs. These related to how, where and why PRME was taking place and what changes it hoped to effect within and beyond the Business School. More studies on the practical implementation of PRME in Business Schools, and the reasons for why some Business Schools resisted the initiative were called for (Arruda Filho 2017). The geographical context in which PRME works was an important factor in articulating future forms of research (Alcaraz and Thiruvattal 2010; Young and Nagpal 2013; Barber et al. 2014; Louw 2015; Oranges Cezarino et al. 2016; Arruda Filho 2017; Beddewela et al. 2017; Décamps et al. 2017; Gentile 2017; Greenberg et al. 2017; Kolb et al. 2017; Singhal et al. 2017; Millar and Price 2018). Studies on PRME outside wealthy, western business school contexts were called for (Verbos and Humphries 2015a, b; Painter-Morland et al. 2016). Additionally, insight into the national and international factors that can help introduce responsibility as a core logic into business schools was advocated (Nhamo and Nhamo 2014; Verbos and Humphries 2015a, b; Sobczak and Mukhi 2016; Gentile 2017). Researchers such as Louw (2015) called for more critical forms of research which would identify and clarify dominant 'economic' Business School paradigms. The study of the language used in and by Business Schools was seen as particularly important in this regard as it was felt that it would lead to greater reflexivity and organizational self-awareness of the values and behaviours which they may be unintentionally encouraging (Louw 2015; Rasche and Gilbert 2015). Critical reflection on the relationship between PRME and corporate values was also highlighted as an area for critical investigation (Dyllick 2015; Millar and Price 2018).

Almost all of the ORME articles proposed that future research be conducted on what actually helps Business Schools become more responsible, particularly in relation to the development of faculty (Maloni et al. 2012; Burchell et al. 2015; Nonet et al. 2015). These articles also advocated more longitudinal research on the students in PRME-accredited Business Schools to ascertain how more responsible forms of management can be encouraged in the corporate world.

Finally, several articles emphasized the importance of inter-faculty research collaboration in making Business Schools more responsible. These papers stressed that research should be conducted with a view to playing a broader public role and by informing policy in the same way that humanities and social science research often does: 'If management research is to live up to the challenges of a deep transformation of economy and society, it will have to change itself dramatically and embrace a responsibility for business in society' (Dyllick 2015, p. 24).

\section{Responsible Individual Learning (RIL)}

Rather than being concerned with initiatives designed and implemented by individual teachers or educational organizations, 'Responsible Individual Learning' (hereafter RIL) is concerned with the individual learner and the processes by which they learn or develop deeper moral understandings of themselves as students or managers. Educational initiatives are mainly discussed in articles in this category in the context of how their curricula hinders or assists processes such as critical thinking, ethical development or the development of reflexive practice (Hibbert and Cunliffe 2015). The RIL category is concerned with how students learn responsibility at the individual level. It must be pointed out that the majority of articles in this category are concerned with individual learners on traditional Business School programmes and only two (Wilson and Brown 2012; Gitsham and Clark 2014) address managers or workers in organizational contexts.

The RIL category included the second largest number of articles in the group $(n=27), 2$ of which were conceptual or theoretical pieces and 7 reported the findings of empirical research on student learning. It is noteworthy that just under one-fifth of the RMLE literature gives attention to individual students; particularly as the first PRME principle is 'Purpose: We will develop the capabilities of students to be future generators of sustainable value for business and society at large and to work for an inclusive and sustainable global economy'. Of these articles, 3 used quantitative data, 2 used qualitative and 2 applied a mixed methodology.

There are four interlinked discernible areas of research concern in the category. As will be mentioned below, most of these focus on the responsible management learner as a participant in a formal educational programme or initiative, usually in a Business School setting. Responsible individual learning is rarely studied in 'live' organizational or workplace contexts.

The first sub-category is concerned with exploring or cultivating values in RMLE. Gentile (2017) demonstrates that the manner in which responsible learning initiatives are taught can impact values-formation amongst students. Both CEOs (Gitsham 2011; Gitsham and Clark 2014) and students (Erskine and Johnson 2012) have articulated that understanding, awareness and appreciation for sustainability is important at all levels throughout business organizations. 
The second area of interest, but the one with the smallest number of articles in the RIL category was concerned with a need to develop a definition and/or clarify key concepts such as responsible management (Nonet et al. 2016), sustainability (Kirby 2012) or responsible leadership development (Smit 2013) with business school students and/or executives.

The largest RIL sub-category was concerned with reporting on the methods used to meaningfully cultivate responsible and sustainable values amongst participating learners in these programmes (Singhal et al. 2018). Although the development of a competency model (Prandini et al. 2012) and the integration of an international standard with PRME (Moratis 2014) were advocated, the majority of the research highlighted that traditional pedagogical approaches were not be of utility in cultivation of responsible values. Instead, approaches which variously integrate experiential learning experiences for students were advocated (Lavine and Roussin 2012; Baden and Parkes 2013). These included explorations of learner experiences of: simulations (Thompson and Milter 2018); life-cycle assessment project management (Sroufe 2013); international student trips (Sroufe et al. 2015); cross-discipline collaboration (Sroufe 2013), and; multi-institutional sustainability education (Dickson et al. 2013).

The final sub-category is concerned with what is arguably one of the most challenging research areas within the RMLE field: informal influences on RIL. Like themes found in other categories, articles in this category challenge the idea that management education is value-free, and that learners are passive recipients of educational 'content'. Some research has studied the influence which business education has on student values and moral competencies (StachowiczStanusch 2011), whilst other work focuses on how being a business student influences one's orientation to responsible management (Haski-Leventhal 2014). Haski-Leventhal et al. (2017) found that the personal characteristics of students, such as gender and age, have been found to influence value formation and attitudes towards CSR and RMLE.

It would be inaccurate to represent all articles in this subcategory as being exclusively concerned with the various moral, personal and cultural backgrounds of learners. Others were concerned with critically appraising the nature of business curricula in order to determine the hidden challenges which emerge from trying to embed RIL in a management programme. Whereas some attempt to integrate PRME principles when drafting student learning outcomes (Singhal et al. 2017), others have highlighted the "profitfirst' mindset that is embedded in much entrepreneurship education can influence how the benefits of sustainabilityoriented programmes are perceived (Lourenco et al. 2013). This concern is perhaps best articulated in Blasco's (2012) study of how the 'hidden curriculum' of management education problematizes attempts to mainstream responsible management learning. Although Business Schools may formally state that they wish to educate business students in ways which encourage responsible practice, informal, tacit, practices create a cultural sub-text for students that communicate other priorities. Studying this hidden curriculum 'can therefore shed light on why students seem to pick up the "wrong" messages about appropriate conduct despite being taught the "right" ones in their CSR classes...' (p. 366). Blasco advocates engaging students in assignments which help them develop a critical mindset in relation to their programmes. Borges et al. (2017a, b) draw attention to the fact that students are not an homogenous group who are solely defined in relation to the programme of study they are registered for. They are also members of communities of practice, which often include student organizations, who are powerful actors in socializing responsible, critical and political behaviours.

The avenues for future potential research proposed by such articles included calls for researching the impact of increased global or international awareness, critical reflection, experiential learning etc., or the individual learners' moral character or propensity to engage with behaviours which are supportive or corporate sustainability or responsibility. As mentioned above, the majority of the research in the category conceives of the responsible individual learning as a participant in a formal Business School programme and the position of the working manager as a responsible management learner embedded in her or his organizational context is discussed. In fact, the perspective of workers and managers (as opposed to traditional students) is only discussed in two articles (Wilson and Brown 2012; Gitsham and Clark 2014). This demonstrates that the position of working managers as responsible individual learners, embedded in their organizational context, is a hugely under-researched and under-theorized field. Research on responsible management is increasingly concerned with 'mainstream' managers, as opposed to CSR or sustainability specialists (Laasch 2018). Just as student engagement with RMLE has been analysed using concepts such as the hidden curriculum and communities of practice, there is an exciting opportunity to study RIL as practiced by individual managers through cultural and critical lenses.

\section{Responsible Organizational Learning (ROL)}

Responsible Organizational Learning (ROL) is explicitly concerned with processes of responsible organizational learning and change, rather than individual learning activities. ROL focuses on responsible learning in the context of the organization, and is interested in how managers collectively learn responsible management in organizational or workplace settings, without the intervention of external educational providers. It would be an error to suggest, 
however, that all organizational change initiatives in this category are solely focused on non-Business Schools. Fougére et al. (2014), for example, demonstrate how the adoption of critical approaches to PRME can disrupt dominant business school vocabularies in a way which can directly influence moral development in faculty and students as a group. Some articles (for example, Cicmil and Gaggiotti 2018) used their 'insider' practitioner perspectives to engage with approaches such as responsible project management education (RPME) explore the complexities of embedding a responsibility orientation in Business Schools. As such, they were considered to be appropriate candidates for inclusion in the ROL category, but as their insights were based on personal experiential reflections on delivering a PM module, rather than studies concerned with responsible change and learning initiatives, it was decided to include them in the TRM category.

Six articles were returned in the ROL category. Abueg et al. (2014) propose a socially responsible (as opposed to entirely profit-driven) model of a firm and present a set of future research objectives which involve testing and developing this model. Wersun (2017) reinforces that top management support for any change initiative also applies to responsible management education initiatives such as PRME; for responsible management learning to occur it needs to be endorsed by the organization at the most senior levels. Sampere (2015) discusses how certain events in the life of an organization can result in transformation and discusses this in the context of business schools and responsible management education. Verbos and Humphries $(2015 \mathrm{a}, \mathrm{b})$ also focus on PRME inspired institutional-level change in the business schools by examining how indigenous values can be integrated into praxis. Doherty et al. (2015) discuss how external market pressures and internal resource barriers prevent authentic embedding of the changes required by PRME.

Even in this category, the Business School/PRME perspective continues to dominate and there is a tangible need to explore stories and theories of responsible management learning and learners in the context of non-educational organizations and businesses. Despite the very small size of this category of articles a strong need exists to develop models of responsible organizational learning which can support responsible organizational change, particularly for organizations in times of crisis (Antonacopoulou and Sheaffer 2014). Research called for in one category is often highlighted as a research need in another. For example, Forray and Leigh state: 'Since the PRME are fundamentally a platform for educational reform, we see the need for more connection to the organizational development and change literatures, and the need to identify the key issues and new models for change management within the higher education context that address fundamental barriers to RME adoption and implementation' (2012, p. 307). This is clearly an area which is also called for in the TRM and ROL categories.

\section{A Research Agenda for RMLE}

There is no uniform RMLE literature; it can be organized into four general categories which have differing areas of focus, but share points of overlap. Research on learning and educating about responsible management has been understood in different ways in various literatures, and the failure to recognize the differences and commonalities of these distinct academic discourses may impede future research initiatives. In order to overcome these problems this paper now turns to articulating a research agenda for RMLE.

Due to the relative newness of PRME, both providercentric RMLE categories (TRM and ORME) have called for more longitudinal research which can determine the long-term impact of responsibility-oriented management and business education on students, faculty members, business schools, universities and businesses. There was also a recognition that PRME is very still very much an initiative of business schools located in the 'Global North' and future research should extend to the field of 'global social responsibility' articulated in the second PRME principle. Both learner-centric RMLE categories (RIL and ROL) focused on established individual or cultural norms which inform the moral 'backgrounds' of individuals or organizations. These articles explored the learning or change processes required to introduce responsibility as a value or caused changes in inherited beliefs about business and management. This is similar to calls for research from researchers in the 'Sustainability in Management Education' (or SiME) movement (Arevalo and Mitchell 2017) and others who have recently called for more research on how learning and education can develop a more environmentally and socially responsible 'mindset' (Figueiro and Raufflet 2015; Cullen 2017; Rimanoczy 2017) or 'ethic' (Bell et al. 2012) amongst management students.

The development of research agendas should do more than distill research needs presented in empirical research papers. A systematic literature review provides opportunities to signpost new avenues which have not been explored to date. As mentioned earlier in this paper, Nonet et al. (2016) write that their literature review on the concept of responsible management found no empirical research on the development of a definition of 'responsible management' and 'reveals the absence of a structured definition' (p. 729). 'Responsibility' in other words, has been discussed as a term which many assume shares the same meaning and nuances for all working in the field. However, scholars working in the fields of leadership studies, law, political science and philosophy have demonstrated that there are a variety of ways in which 'responsibility' has been conceptualized (Satkunanandan 2015; Voegtlin 
2016; Young 2011). Research on the language used in the RMLE literature should seek to discover what particular forms of responsibility tend to be discussed in order to determine what other types are possible in relation to RMLE? Future research on the language of responsibility in the RMLE literature could investigate to what extent are disruptive forms of responsibility encouraged by learning initiatives. 'If the goal of PRME is responsible management education, its implementation should not be about creating spaces only for comfort and complacency but also for the discomfort of reflexivity and, ultimately, change' (Solitander et al. 2012, p. 360).

A second important area where future research might develop is related to, but distinct, from the need articulated in the literature for more longitudinal forms of RMLE research. Calls for longitudinal research seek to find out if responsible learning initiatives create new forms of learning 'entities or 'selves' at the individual level, and 'organizations' at the institutional level. Burgoyne (2002) review of learning theories identified 14 theories of learning, which in turn suggested a 14 associated forms of 'self' or 'learning entity' which are the outcomes of each form of training. Burgoyne reviewed the literature on various learning theories and distilled the key concepts, the orientation the facilitation of learning from educators and the type of learning which each learning theory seeks to attain. A similar analysis of the learning entities sought in the literature contained in the four RMLE categories would provide a useful clarification of the types of learners (both individuals and organizational) which each type of learning approach aims to produce.

Godeman et al.'s review of PRME signatory Sharing Information on Progress (SIP) reports

'suggest that management education institutions initially focused on the development of new modules and programs which focus specifically on social responsibility and sustainability or have critically reflected the syllabus of individual modules and programs. However, in their 2010/11 SIP reports many management education institutions stressed they were planning to reviewing teaching, with the aim of embedding social responsibility and sustainability to cover all undergraduate and postgraduate programs' (2014, p. 19).

Future research might also review these reports to ascertain how responsible learning and learners are conceptualized outside the peer-reviewed research literature.

This review has highlighted that issues which exist in one category of the literature, manifest in a different way in others. For example, the finding that gender influences a faculty member's orientation to RMLE (Asirvatham and Humphries-Kil 2017) in the TRM category is reflected in the gendered nature of student openness to ethical learning in the RIL category (Haski-Leventhal et al. 2017). Similarly, the need for business schools to resolve the tension between capitalism and social/environmental responsibility in the ORME category (e.g Millar and Koning 2018) is also experienced by individual teachers and learners in both the TRM (Aragon-Correa et al. 2017; Neal 2017) and RIL literatures (Blasco 2012). The shared nature of these concerns indicates rich opportunities for conceptual and practical cross-fertilization across the different RMLE categories. As mentioned above, some papers in the ORME category find the espoused value-neutrality of management education to be problematic. Louw's (2015) Critical Discourse Analysis, for example, found PRME to promote an understanding of Business Schools as allies and servants of the capitalist private sector. This creates difficulties as PRME espouses a paradigm change in business and management education. Fougere et al. (2014) and Blasco's (2012) work in the RIL category, however, asserts that identifying and critiquing these Business School values can lead to moral development amongst learners. These values can, in turn, be espoused by Business Schools in an effort that not only can generate new values, but result in the development of moral learning capabilities for students.

Antonacopoulou (2016) has highlighted that individual management learning processes are interrelated with the organizational contexts in which they occur. This is particularly true of the ROL literature, which this Special Issue speaks to. Laasch (2018) writes that the development concept of 'responsible management' as a field of practice and study has involved shifts towards the individual 'mainstream' manager and their practices and away from organizational level initiatives, academic theories and specialized 'ethics-focused' managerial roles. The development of the field of responsible management learning thus requires research into how ethical principles of sustainability and responsibility become embedded into organizational and managerial practice (Laasch and Moosmayer 2015b). To understand how managers learn responsibly more research is required that will addresses the individual manager in the context of their organizational locale, and how this learning is used in practice.

\section{Discussion}

\section{Limitations}

Although there has been much research conducted on responsible management education and learning, this is the first systemic literature review on the topic. As such there are many ways in which future research can add to this discussion and it is important to highlight shortfalls of the current project so future research can address them. Firstly, all of the peer-reviewed articles reviewed were 
written in English. Although English has become the lingua franca of scholarship, it is important to recognize that significant volumes of work have been published not only in the RMLE fields, but on responsible management in general (such as the Centre for Responsible Management Education's RM Literature Base). It is especially important that this literature be reviewed and incorporated into future studies, particularly as much of RMLE literature has highlighted the absence of input from Business Schools in less-wealthy regions as a significant barrier to the development of the field.

This systematic review has been undertaken on peerreviewed literature only. This means that work on RMLE published outside formal scholarly journals has not been taken into account in this review. Adams et al. (2016) have recently re-visited the rationale for excluding research-based 'grey literature' in systematic reviews and suggested a new set of guidelines for how certain forms of output which has not been subject to peer-review might be included in order to improve impact. As the ORME literature has articulated a need to engage with broader audiences outside the purely academic, it is important that this be taken into account in future bibliometric studies or literature reviews of the RMLE field.

Finally, 'responsibility' has become central to ethical and moral education and learning in the field of business, management and organizational studies and this is no doubt due to the implementation of PRME. This review took responsibility as its focus and related it to management education, learning, training, Human Resource Development, teaching, etc. This means that other search terms which could possibly have been studied in the field might have been missed as a result of this focus. Similar future studies might address this through the inclusion of search terms such as: moral, ethical; altruistic, sustainable, benevolent, value, etc.

\section{Summary and Conclusion}

This paper began from a concern that the field of RMLE was being discussed in a way that did not address it's diversity, and that this lack of awareness might impede the future development of the field. There is not one RMLE research literature. A systematic literature of the RMLE literature demonstrated that there is a much greater volume of provider-centric than learner-centric research literature. The corpus of existing research in the field be sub-divided into four main categories:

- Teaching Responsible Management (TRM) explores the teaching activities of individual teachers, often by these teachers themselves;
- Organizing for Responsible Management Education (ORME) largely discusses the implementation of PRME in Business Schools;

- Responsible Individual Learning (RIL) mainly researches how students learn about responsibility, and how this learning is influenced by 'hidden curricula', personal or social factors;

- Responsible Organizational Learning (ROL) is concerned with how change initiatives in organizations and groups of managers within organizations, may learn and change in socially and environmentally responsible ways. This is the most under-studied and untheorized category of RMLE, and the need for conceptual and empirical work on how managers learn responsibly in their own organizational context is a significant gap in existing knowledge.

All of these literatures emphasize that opportunities for research in one category could inform research in others. In addition, many of the papers reviewed advocated greater amounts of cross-disciplinary studies. A noticeable theme was the need for RMLE research to impact not only beyond Business Schools, but also in less-developed economic systems, as well as on public policy related to global social and environmental challenges.

Despite the volume of literature there is still a lack of understanding about various possible varieties of 'responsibility' in the management literature. It is important that this be investigated so new models of RMLE can develop. These in turn can help address the lack of formal understandings of what 'responsible management' means in a more general sense. There is a distinct need to understand the types of learning 'entities' (selves, organizations) RMLE seeks to produce that are different to the traditional management learners which Business Schools have sought to produce until now.

By identifying four distinct strands within the RMLE literature, there is an enormous potential for growing this nascent field of study, and for adopting the models and approaches utilized by other disciplines in education, the humanities and social sciences.

\section{Compliance with Ethical Standards}

Ethical Approval This article does not contain any studies with human participants or animals performed by any of the authors.

\section{References}

Abueg, L. C., Sauler, M. M. R., \& Teehankee, B. L. (2014). Towards a common good model of the firm. DLSU Business \& Economics Review, 24, 1-12.

Adams, R. J., Smart, P., \& Sigismund Huff, A. (2016). Shades of grey: Guidelines for working with the grey literature in 
systematic reviews for management and organizational studies. International Journal of Management Reviews, 1-23 (Open Access Online).

Aguinis, H., \& Glavas, A. (2012). What we know and don't know about corporate social responsibility: A review and research agenda. Journal of Management, 38, 932-968.

Alcaraz, J. M., \& Thiruvattal, E. (2010). An interview with Manuel Escudero: The United Nations' principles for responsible management education: A global call for sustainability. Academy of Management Learning and Education, 9, 542-550.

Amann, W. (2011). Business schools under fire: Humanistic management education as the way forward. Basingstoke: Palgrave Macmillan.

Annan-Diab, F., \& Molinari, C. (2017). Interdisciplinarity: Practical approach to advancing education for sustainability and for the Sustainable Development Goals. International Journal of Management Education, 15, 73-83.

Antonacopoulou, E. P. (2016). The relationship between individual and organizational learning: New evidence from managerial learning practices. Management Learning, 37, 455-473.

Antonacopoulou, E. P., \& Sheaffer, Z. (2014). Learning in crisis: Rethinking the relationship between organizational learning and crisis management. Journal of Management Inquiry, 23, $5-21$.

Araç, S. K., \& Madran, C. (2014). Business school as an initiator of the transformation to sustainability: A content analysis for business schools in PRME. Social Business, 4, 137-152.

Aragon-Correa, J. A., Marcus, A. A., Rivera, J. E., \& Kenworthy, A. L. (2017). sustainability management teaching resources and the challenge of balancing planet, people, and profits. Academy of Management Learning and Education, 16, 469-483.

Arevalo, J. A., \& Mitchell, S. F. (2017). Handbook of sustainability in management education: In search of a multidisciplinary, innovative and integrated approach. Cheltenham, UK Northampton, MA: Edward Elgar Publishing.

Arruda Filho, N. D. P. (2017). The agenda 2030 for responsible management education: An applied methodology. International Journal of Management Education, 15, 183-191.

Asirvatham, S., \& Humphries-Kil, M. (2017). Feminist reflections on life in (im)balance, career praxis, and the PRME. International Journal of Management Education, 15, 126-137.

Baden, D., \& Parkes, C. (2013). Experiential learning: Inspiring the business leaders of tomorrow. Journal of Management Development, 32, 295-308.

Barber, N. A., Wilson, F., Venkatachalam, V., Cleaves, S. M., \& Garnham, J. (2014). Integrating sustainability into business curricula: University of New Hampshire case study. International Journal of Sustainability in Higher Education, 15, 1-23.

Beddewela, E., Warin, C., Hesselden, F., \& Coslet, A. (2017). Embedding responsible management education-staff, student and institutional perspectives. International Journal of Management Education, 15, 263-279.

Bell, E., Cullen, J., \& Taylor, S. (2012). Sustainability and the spiritual work ethic. In P. Case, H. Hopfl, \& H. Letiche (Eds.), Belief and organization (pp. 185-203). Basingstoke, Hampshire: Palgrave Macmillan.

Bendell, J. (2007). The responsibility of business schools. Journal of Corporate Citizenship, 28, 4-14.

Bennis, W. G., \& O’Toole, J. (2005). How Business Schools lost their way. Harvard Business Review, 83, 96-104.

Blasco, M. (2012). Aligning the hidden curriculum of management education with PRME: An inquiry-based framework. Journal of Management Education, 36, 364-388.
Borges, J. C., Cezarino, L. O., Ferreira, T. C., Sala, O. T. M., Unglaub, D. L., \& Caldana, A. C. F. (2017a). Student organizations and communities of practice: Actions for the 2030 Agenda for Sustainable Development. International Journal of Management Education, 15, 172-182.

Borges, J. C., Ferreira, T. C., Borges de Oliveira, M. S., Macini, N., \& Caldana, A. C. F. (2017b). Hidden curriculum in student organizations: Learning, practice, socialization and responsible management in a business school. International Journal of Management Education, 15, 153-161.

Burchell, J., Kennedy, S., \& Murray, A. (2015). Responsible management education in UK business schools: Critically examining the role of the United Nations Principles for Responsible Management Education as a driver for change. Management Learning, 4, 479-497.

Burgoyne, J. G. (2002). Learning theory and the construction of self: What kinds of people do we create through the theories of learning that we apply to their development?'. In M. Pearn (Ed.), Individual differences and development in organizations. Chichester: Wiley.

Cicmil, S., \& Gaggiotti, H. (2018). Responsible forms of project management education: Theoretical plurality and reflective pedagogies'. International Journal of Project Management, $36,208-218$.

Cornuel, E., \& Hommel, U. (2015). Moving beyond the rhetoric of responsible management education. Journal of Management Development, 34, 2-15

Csuri, M., Laasch, O., Nahser, R., \& Weybrecht, G. (2013). Inspirational guide for the implementation of PRME: Learning to go beyond. Sheffield: Greenleaf.

Cullen, John G. (2017). Educating business students about sustainability: A bibliometric review of current trends and research needs. Journal of Business Ethics, 145, 429-439.

Cullen, J., \& Turnbull, S. (2005). A meta-review of the management development literature. Human Resource Development Review, 4, 335-355.

Décamps, A., Barbat, G., Carteron, J. C., Hands, V., \& Parkes, C. (2017). Sulitest: A collaborative initiative to support and assess sustainability literacy in higher education. International Journal of Management Education, 15, 138-152.

Dickson, M. A., Eckman, M., Loker, S., \& Jirousek, C. (2013). A model for sustainability education in support of the PRME. Journal of Management Development, 32, 309-318.

Doherty, B., Meehan, J., \& Richards, A. (2015). The business case and barriers for responsible management education in business schools. Journal of Management Development, 34, 34-60.

Dyllick, T. (2015). Responsible management education for a sustainable world. Journal of Management Development, 34, 16-33.

Education, P.f.R.M. (2012). Inspirational guide for the implementation of PRME. Sheffield: GSE Research.

Erskine, L., \& Johnson, S. D. (2012). Effective learning approaches for sustainability: A student perspective. Journal of Education for Business, 87, 198-205.

Figueiro, P. S., \& Raufflet, E. (2015). Sustainability in higher education: A systematic review with focus on management education. Journal of Cleaner Production, 106, 22-33.

Forray, J. M., \& Leigh, J. S. A. (2012). A primer on the Principles of Responsible Management Education: Intellectual roots and waves of change. Journal of Management Education, 36, 295-309.

Fougère, M., Solitander, N., \& Young, S. (2014). Exploring and exposing values in management education: Problematizing final vocabularies in order to enhance moral imagination. Journal of Business Ethics, 120, 175-187. 
Gentile, M. C. (2017). Giving voice to values: A global partnership with UNGC PRME to transform management education. International Journal of Management Education, 15, 121-125.

Ghoshal, S. (2005). Bad management theories are destroying good management practices. Academy of Management Learning and Education, 4, 75-91.

Gitsham, M. (2011). CEO perspectives: Management education in a changing context. Corporate Governance: The International Journal of Effective Board Performance, 11, 501-512.

Gitsham, M., \& Clark, T. S. (2014). Market demand for sustainability in management education. International Journal of Sustainability in Higher Education, 15, 291-303.

Godemann, J., Haertle, J., Herzig, C., \& Moon, J. (2014). United Nations supported principles for responsible management education: Purpose, progress and prospects. Journal of Cleaner Production, 62, 16-23.

Goodpaster, K. E., Dean Maines, T., Naughton, M., \& Shapiro, B. (2018). Using UNPRME to teach, research, and enact business ethics: Insights from the Catholic Identity Matrix for Business Schools. Journal of Business Ethics, 147, 761-777.

Greenberg, D. N., Deets, S., Erzurumlu, S., Hunt, J., Manwaring, M., Rodgers, V., et al. (2017). Signing to living PRME: Learning from a journey towards responsible management education. International Journal of Management Education, 15, 205-218.

Gudic, M., Parkes, C., \& Rosenbloom, A. (2016). Responsible management education and the challenge of poverty. Sheffield: Greenleaf.

Haski-Leventhal, D. (2014). MBA student values, attitudes and behaviors: A cross-cultural comparison of PRME Signatory Schools. SAM Advanced Management Journal, 79, 29-41.

Haski-Leventhal, D., Pournader, M., \& McKinnon, A. (2017). The role of gender and age in business students' values, CSR attitudes, and responsible management education: Learnings from the PRME international survey. Journal of Business Ethics, 146, 219-239.

Heaton, D. P. (2017). Stop teaching: Principles and practices for responsible management education. Academy of Management Learning and Education, 16, 165-167.

Hibbert, P., \& Cunliffe, A. (2015). Responsible management: Engaging moral reflexive practice through threshold concepts. Journal of Business Ethics, 127, 177-188.

Kelley, S., \& Nahser, R. (2014). Developing sustainable strategies: Foundations, method, and pedagogy. Journal of Business Ethics, 123, 631-644.

Kirby, S. L. (2012). Implementing the Principles of Responsible Management Education: Examining understandings of economic, social, and environmental sustainability. Journal of Strategic Management Education, 8, 61-76.

Kolb, M., Fröhlich, L., \& Schmidpeter, R. (2017). Implementing sustainability as the new normal: Responsible management education: From a private business school's perspective. International Journal of Management Education, 15, 280-292.

Laasch, O. (2016). What is responsible management learning and education (RMLE)? CRME Working Paper 2(1). Center for Responsible Management Education.

Laasch, O. (2017). Responsible management, learning and education: Towards a transdiscipline of sustainability, responsibility, ethics. CRME Working Paper 3(1). Center for Responsible Management Education.

Laasch, O. (2018). Just old wine in new bottles? Conceptual shifts in the emerging field of responsible management. CRME Working Papers, 4(1).

Laasch, O., \& Conaway, R. N. (2015). Principles of responsible management: Glocal sustainability, responsibility, ethics. Mason: Cengage.
Laasch, O., \& Conaway, R. N. (2016). Responsible business: The textbook for management learning, competence and innovation (2nd ed.). Sheffield: Greenleaf.

Laasch, O., \& Moosmayer, D. (2015). Competences for responsible management education: A structured literature review, CRME Working Papers, 1(2). Center for Responsible Management Education.

Laasch, O., \& Moosmayer, D. (2015). Responsible management learning: Reflecting on the role and use of paradigms for research in sustainability, responsibility, ethics research, CRME Working Papers 1(2). Center for Responsible Management Education.

Lavine, M. H., \& Roussin, C. J. (2012). From idea to action: Promoting responsible management education through a semester-long academic integrity learning project. Journal of Management Education, 36, 428-455.

Lenn, D. J. (2015). Principles of responsible management: Glocal sustainability. Responsibility, and Ethics, Academy of Management Learning and Education, 14, 299-301.

Lourenco, F., Jones, O., \& Jayawarna, D. (2013). Promoting sustainable development: The role of entrepreneurship education. International Small Business Journal, 31, 841-865.

Louw, J. (2015). "Paradigm change" or no real change at all? A critical reading of the U.N. Principles for Responsible Management Education. Journal of Management Education, 39, 184-208.

Maloni, M. J., Smith, S. D., \& Napshin, S. (2012). A methodology for building faculty support for the United Nations Principles for Responsible Management Education. Journal of Management Education, 36, 312-336.

Marshall, J. D., \& Toffel, M. W. (2005). Framing the elusive concept of sustainability: A sustainability hierarchy. Environmental Science and Technology, 39, 673-682.

Millar, J., \& Koning, J. (2018). 'From capacity to capability? Rethinking the prime agenda for inclusive development in management education. African Journal of Business Ethics, 12, 22-37.

Millar, J., \& Price, M. (2018). Imagining management education: A critique of the contribution of the United Nations PRME to critical reflexivity and rethinking management education. Management Learning, 49, 346-362.

Mintzberg, H. (2004). Managers not MBAs: A hard look at the soft practice of managing and management development. New Jersey: Pearson Education.

Mocny, F., \& Laasch, O. (2010). Inspirational guide: Implementing the PRME in executive degree programs. New York: United Nations Principles for Responsible Management Education.

Moosmayer, D., Laasch, O., Parkes, C., \& Brown, K. (2019). The Sage handbook of responsible management learning and education. Thousand Oaks: Sage.

Moratis, L. (2013). A tale of two standards on responsible management education. Journal of Global Responsibility, 4, 138-156.

Moratis, L. (2014). ISO 26000. Journal of Corporate Citizenship, 53, 77-90.

Moratis, L. (2016). Decoupling management education: Some empirical findings, comments, and speculation. Journal of Management Inquiry, 25, 235-239.

Murphy, R., Sharma, N., \& Moon, J. (2012). Empowering students to engage with responsible business thinking and practices. Business and Professional Ethics Journal, 31, 313-330.

Murray, A., Badan, D., Cashian, P., Haynes, K., \& Wersun, A. (Eds.). (2014). Inspirational guide for the implementation of PRME, UK and Ireland. Sheffield: Greenleaf.

Neal, M. (2017). Learning from poverty: Why business schools should address poverty, and how they can go about it. Academy of Management Learning and Education., 16, 54-69.

Nhamo, S., \& Nhamo, G. (2014). Assessing progress in implementing UN PRME: International perspectives and lessons from South Africa. Problems and Perspectives in Management, 12, 94-108. 
Nonet, G., Kassel, K., \& Meijs, L. (2016). Understanding responsible management: Emerging themes and variations from European business school programs. Journal of Business Ethics, 139, 717-736.

Nonet, G., Kassel, K., \& Rodhain, F. (2015). How do Business Schools support internal innovation and work on their strategy and their reputation? The case of responsible management. Journal of Innovation, Economics and Management, 2, 69-98.

Oranges Cezarino, L., Duarte Couto Fernandes, V., Alves Soares, M., de Castro Carrijo, M., \& Cardoso Abdala, E. (2016). Teachers' opinion about sustainability on management education. Business Management Dynamics, 6, 1-8.

Painter-Morland, M. (2015). Philosophical assumptions undermining responsible management education. Journal of Management Development, 34, 61-75.

Painter-Morland, M., Sabet, E., Molthan-Hill, P., Goworek, H., \& de Leeuw, S. (2016). Beyond the curriculum: Integrating sustainability into Business Schools. Journal of Business Ethics, 139, 737-754.

Parris, D. L., \& McInnis-Bowers, C. (2017). Business not as usual: Developing socially conscious entrepreneurs and intrapreneurs. Journal of Management Education, 41, 687-726.

Prandini, M., Isler, P. V., \& Barthelmess, P. (2012). Responsible management education for 21st century leadership. Central European Business Review, 1, 16-22.

Rasche, A., \& Escudero, M. (2009). Leading change. Zeitschrift fuer Wirtschafts und Unternehmensethik, 10, 244-250.

Rasche, A., \& Gilbert, D. U. (2015). Decoupling Responsible management education: Why business schools may not walk their talk. Journal of Management Inquiry, 24, 239-252.

Rimanoczy, I. (2016). Stop teaching: Principles and practices for responsible management education. New York: Business Expert Press.

Rimanoczy, I. (2017). Developing the sustainability mindset: In search of a multidisciplinary, innovative and integrated approach. In J. A. Arevalo \& S. F. Mitchell (Eds.), Handbook of sustainability in management education: In search of a multidisciplinary innovative and integrated approach (pp. 221-241). Cheltenham, UK; Northampton, MA: Edward Elgar Publishing.

Rive, J., Bonnet, M., Parmentier, C., Pelazzo-Plat, V., \& Pignet-Fall, L. (2017). A contribution to the laying of foundations for dialogue between socially responsible management schools. International Journal of Management Education, 15, 238-248.

Rosenbloom, A., Gudić, M., Parkes, C., \& Kronbach, B. (2017). A PRME response to the challenge of fighting poverty: How far have we come? Where do we need to go now? International Journal of Management Education, 15, 104-120.

Sampere, J. P. V. (2015). How the evolution of science will transform business schools. Journal of Management Development, 34, 101-112.

Satkunanandan, S. (2015). Extraordinary responsibility: Politics beyond the moral calculus. New York: Cambridge University Press.

Schwartz, M. S., \& Carroll, A. B. (2008). Integrating and unifying competing and complementary frameworks: The search for a common core in the business and society field. Business and Society, 47, 148-186.

Singhal, N., Gupta, H., \& Mittal, G. (2018). Importance-performance analysis to identify effective learning approaches for sustainability in an Indian business school. Vision, 22, 276-283.

Singhal, N., Suryawanshi, P., \& Mittal, G. (2017). Crafting responsible management practices in Business School learning outcomes: An Indian case study. Vision, 21, 46-62.

Siqueira, A. C. O., \& Ramos, D. P. (2014). Preparing students to address world challenges through international and crosscultural active learning: A focus on sustainability and social entrepreneurship. Journal of International Business Education, 9, $145-166$.

Smit, A. (2013). Responsible leadership development through management education: A business ethics perspective. African Journal of Business Ethics, 7, 45-51.

Snelson-Powell, A., Grosvold, J., \& Millington, A. (2016). Business school legitimacy and the challenge of sustainability: A fuzzy set analysis of institutional decoupling. Academy of Management Learning and Education, 15, 703-723.

Sobczak, A., \& Mukhi, U. (2016). The role of UN Principles for Responsible Management Education in stimulating organizational learning for global responsibility within business schools: An interview with Jonas Haertle. Journal of Management Inquiry, 25, 431-437.

Solitander, N., Fougère, M., Sobczak, A., \& Herlin, H. (2012). We are the champions: Organizational learning and change for responsible management education. Journal of Management Education, 36, 337-363.

Sroufe, R. (2013). 'Life Cycle Assessment within MBA courses: A tool for integrating sustainability. Operations Management Education Review, 7, 95-130.

Sroufe, R., Sivasubramaniam, N., Ramos, D., \& Saiia, D. (2015). Aligning the PRME: How study abroad nurtures responsible leadership'. Journal of Management Education, 39, 244-275.

Stachowicz-Stanusch, A. (2011). The impact of business education on students' moral competency: An exploratory study from Poland. Vision, 15, 163-176.

Stough, T., Ceulemans, K., Lambrechts, W., \& Cappuyns, V. (2018). Assessing sustainability in higher education curricula: A critical reflection on validity issues. Journal of Cleaner Production, 172, 4456-4466.

Thompson, L., \& Milter, R. G. (2018). 'CityLab: An academic business capstone for the urban century. Business and Professional Ethics Journal, 37, 213-235.

Tripathi, S. K., Amann, W., \& Kamuzora, F. R. (2014). Developing responsible managers for new generation organizations: Why existing business education system needs humanistic shift. $3 D$ IBA Journal of Management and Leadership, 6, 56-63.

Tyran, K. L. (2017). Transforming students into global citizens: International service learning and PRME. International Journal of Management Education, 15, 162-171.

Verbos, A. K. (2016). Embedding the PRME in business law classes Journal of Higher Education Theory and Practice, 16, 11-24.

Verbos, A. K., \& Humphries, M. (2015a). Amplifying a relational ethic: A contribution to PRME Praxis. Business and Society Review, 120, 23-56.

Verbos, A. K., \& Humphries, M. T. (2015b). Indigenous wisdom and the PRME: Inclusion or illusion? Journal of Management Development, 34, 90-100.

Viswanathan, M. (2012). Curricular innovations on sustainability and subsistence marketplaces: Philosophical, substantive, and methodological orientations. Journal of Management Education, 36, 389-427.

Voegtlin, C. (2016). What does it mean to be responsible? Addressing the missing responsibility dimension in ethical leadership research. Leadership, 12, 581-608.

Waddock, S., Rasche, A., Werhane, P. H., \& Unruh, G. (2010). The principles for Responsible Management education: Where do we go from here? In D. F. D. Swanson (Ed.), Got ethics? Toward assessing business education (pp. 13-28). Charlotte: Information Age Publishing.

Warwick, P., Wyness, L., \& Conway, H. (2017). 'Think of the future': Managing educational change from students' perspectives of an undergraduate sustainable business programme. International Journal of Management Education, 15, 192-204. 
Wersun, A. (2017). Context and the insitutionalisation of PRME: The case of the University for the Common Good. International Journal of Management Education, 15, 249-262.

Wilson, M. S., \& Brown, J. M. (2012). The perceptions of dislocated workers under the Workforce Investment Act. Human Resource Development Quarterly, 23, 389-410.

Young, I. M. (2011). Responsibility for justice. New York: Oxford University Press.

Young, S., \& Nagpal, S. (2013). Meeting the growing demand for sustainability-focused management education: a case study of a PRME academic institution. Higher Education Research and Development, 32, 493-506.

Publisher's Note Springer Nature remains neutral with regard to jurisdictional claims in published maps and institutional affiliations. 